\title{
Comparative analysis of trypsin inhibitor levels in sweet potato cultivars in Sri Lanka
}

\author{
Suraji Senanayake ${ }^{1 *}$, K.K.D.S. Ranaweera ${ }^{1}$, Arthur Bamunuarachchi ${ }^{1}$ and Anil Gunaratne ${ }^{2}$ \\ ${ }^{I}$ Department of Food Science and Technology, Faculty of Applied Sciences, University of Sri Jayewardenepura, Gangodawila, Nugegoda. \\ ${ }^{2}$ Faculty of Agricultural Sciences, Sabaragamuwa University of Sri Lanka, Belihuloya.
}

Revised: 11 October 2013; Accepted: 11 December 2013

\begin{abstract}
Sweet potato [Ipomea batatas (L) Lam.] is a commonly consumed root crop in Sri Lanka. A study was undertaken to estimate the nutritional aspects in terms of trypsin inhibitory activity (TIA) of five different cultivars of sweet potato (SWP1 - Wariyapola red, SWP3 - Wariyapola white, SWP4 - Pallepola, SWP5 - Malaysian variety and SWP7 - CARI 273) commonly consumed in Sri Lanka. The moisture level ranged between $65.0 \pm 3.4$ and $74.6 \% \pm 1.9$ and the crude protein content varied between $1.2 \pm 0.1$ and $3.3 \% \pm$ 0.1 . The TIA in unheated and heated sweet potato root samples varied between $1.9 \pm 0.01$ to $15.4 \pm 0.4$ and $0.156 \pm 0.01$ to 13.0 \pm 0.01 , respectively. In all the cultivars studied the TIA was significantly different at $\mathrm{p}<0.05$ and there was a significant reduction in TIA levels in all the heated samples compared to the raw samples. The highest TIA level was observed in SWP4 and the lowest in SWP1 in both heated and unheated samples. In terms of nutritive quality, SWP 7 cultivar was comparatively superior to the other cultivars studied with regard to the dry matter content, crude protein level and the TIA level per gram of protein. It may be possible to improve the nutritive quality of other cultivars through crop enhancing with high protein levels while lowering the TIA.
\end{abstract}

Keywords: Crude protein, moisture, sweet potato, trypsin inhibitor activity.

\section{INTRODUCTION}

Sweet potato [Ipomea batatas (L) Lam.] is a tuberousrooted perennial plant belonging to Convolvulaceae or the morning glory family and includes about 45 genera and 1000 species, but only Ipomea batatas is of economic importance as food (Onwueme, 1978). The main sources of starch of the world today are corn, cassava, potato, wheat and rice (Alves et al., 2002). Sweet potato is one of the important sources of calories for people in the developing countries and is the seventh most important food crop grown in more than hundred countries. It is an important staple food for large sectors of the world population in the tropics where both the roots and tender shoots are eaten as a vital source of nutrients (Woolfe, 1992).

Sweet potato has a remarkable ability to convert solar and soil energies into carbohydrates, giving impressive yields under marginal and stress situations and requires a minimum amount of agricultural inputs and attention. The bulk of the production is now concentrated in Asia. China accounts for about $80 \%$ of the world's production where roots are used as food, animal feed and as raw material for starch and noodle manufacture (Woolfe, 1992). Today, the main commercial producers of sweet potato are China, Indonesia, Vietnam, Japan, India and Uganda. Adaptability to extreme environmental conditions, flexibility in crop management and nonseasonality make sweet potato a viable crop in all agro ecological zones excluding high elevations. Sweet potato is rich in starch, soluble sugars, vitamins, minerals and other nutrients. The high nutritive quality, the richness in starch and the physico-chemical properties in sweet potato flour and starch can be used to increase its utilization as a food crop for humans and livestock, and for food industrial applications in Sri Lanka.

A major anti - nutritional factor of sweet potato is the presence of high level of protease inhibitors. 
Protease inhibitors occur naturally in microorganisms, plants and animals (Liener \& Kakade, 1969). They play an important role in plants in regulating and controlling endogenous protease and acting as protective agents against insect and / or microbial proteases (Ryan, 1989). Trypsin inhibitors (TI) were first isolated by Kunitz in 1945 in soybean (Liener \& Kakade, 1969). This group of protease inhibitors suppresses the action of proteases and makes proteins nutritionally unavailable. The effects of processing methods on TI, particularly in soybean-related foods have been studied extensively. These inhibitors can be inactivated by heat treatment and thereby improve the nutritive quality of the foodstuff.

The presence of TI in sweet potato was first reported by Sohonnie \& Bhandarker (1954). TI in sweet potato storage roots account for about $60 \%$ of the total water soluble proteins and could be recognized as storage proteins (Lin, 1989). It was reported that uncooked sweet potato roots in animal feed reduced the growth rate of pigs (Bouwkamp et al., 1985). Poor protein digestibility due to TI present in sweet potato might be a constraint in promoting the use of sweet potato as animal feed. The levels of trypsin inhibitor activity (TIA) in sweet potato cultivars have been reported earlier (Bradbury et al., 1985; Ravindran et al., 1995; Zhang et al., 1998). The effects of heat treatments on TIA in vines, leaves and roots of certain sweet potato cultivars have been investigated by Zhang et al. (2002).

Matsuoka et al. (1990) has identified sporamin as the major soluble storage protein in sweet potato roots, which accounts for about $80 \%$ of the total storage proteins. Considerable amounts of original sporamin levels in roots were found to decrease during sprouting. Lin (1989) also considered sporamin as one form of trypsin inhibitors available in sweet potato roots. It was found that NADPH / thioredoxin system in sweet potato roots play an essential role in modifying TI to become more soluble and susceptible for proteolysis, thus the released amino acids could be utilized during sprouting (Jiao et al., 1992; Kobrehel et al., 1992). Bouwkamp et al. (1985) revealed a significant level of positive correlation between the TI levels and protein concentration in sweet potato roots. Sporamin helps in the germination process (Lin, 1989) and acts as an anti - insect agent. Therefore, TIA is a critical factor for insect resistance and the level of TIA is directly related to the anti - insect capability (Cai et al., 2003). Sporamin falls into two distinct homology groups, subfamilies A and B and it is difficult to separate purified sporamin A or B due to their similar structures (Yan - Li et al., 2009). Three trypsin inhibitors - inhibitor I, II and III were isolated by Sugiura et al. in 1973 from the tuberous roots of sweet potato.
In Sri Lanka, sweet potato is a traditional crop grown mainly in the Wet and Intermediate Zones. Sweet potato cultivation is restricted to about $8,383 \mathrm{Ha}$ and about $51,582 \mathrm{Mt}$ per year of gross production was obtained annually in Sri Lanka (DCS Sri Lanka, 1999). All of this production is used for human consumption since high consumer preference for roots prevents its utilization as an animal feed. Sweet potato is mainly consumed by low income people since it is one of the cheap substitutes for starchy staples such as rice, wheat and potato (De Silva \& Jayawardena, 1989). The fresh tubers are commonly eaten boiled or as a curry with other food ingredients and in rural areas the leaves are also consumed as a leafy vegetable.

The amount of protein and TIA levels in heated and unheated sweet potato flour samples from five different cultivars commonly available in the local market were analyzed in this study. The main objective was to analyze the TIA levels in heated and unheated sweet potato roots and understand the nutritional quality of this crop with respect to heat treatment in order to increase its utilization, so as to overcome the existing nutritional deficiencies in the country.

\section{METHODS AND MATERIALS}

\section{Materials}

Mature tubers of sweet potato cultivars namely, SWP1 (Wariyapola red), SWP3 (Wariyapola white), SWP4 (Pallepola variety), SWP5 (Malaysian variety) and SWP7 (CARI 273) were randomly collected from three different locations in Dambulla, Gokarella and Horana areas in Sri Lanka and prepared for analysis two to three days after harvesting. Trypsin from porcine pancreas, BAPNA and DMSO were purchased from SigmaAldrich, USA.

\section{Sample preparation}

The roots were washed, hand peeled and trimmed to remove defective parts. Then the tubers were grated into thin chips $(\sim 5 \mathrm{~mm})$ and dried in an air convention oven at $40{ }^{\circ} \mathrm{C}$ for $30 \mathrm{hrs}$ to reduce the moisture up to $14 \%$. The dried chips were powdered using a laboratory scale grinder and sifted through a $300 \mu \mathrm{m}$ sieve. The flour samples were sealed and packed in air - tight containers for further analysis.

\section{Flour extractability, moisture and protein content}

The levels of flour extractability was calculated from fresh roots (weight of flour/ fresh weight $\times 100$ ) and 
the moisture level and protein content $(\mathrm{N} \times 6.25)$ were determined using the methods described by AOAC (1980).

\section{Trypsin inhibitory activity (TIA) analysis}

The TIA was analysed in unheated and heated samples $\left(100{ }^{\circ} \mathrm{C}\right.$ for $5 \mathrm{~min}$ ) by using the method described by Smith et al. (1980).

\section{Reagent preparation}

Tris buffer : Tris $0.05 \mathrm{M}$ buffer was prepared by dissolving $2.94 \mathrm{~g}$ of $\mathrm{CaCl}_{2} \cdot 2 \mathrm{H}_{2} \mathrm{O}$ and $6.05 \mathrm{~g}$ Tris hydroxymethyl methylamine in $900 \mathrm{~mL}$ of distilled water and the $\mathrm{pH}$ was adjusted to 8.2 by adding $\mathrm{HCl}$. The total volume was brought up to $1 \mathrm{~L}$ and the $\mathrm{pH}$ was re-checked.

BAPNA solution: $80 \mathrm{mg}$ of BAPNA (Benzoyl - DL - arginine $-p$ - nitroanilide hydrochloride) substrate was completely dissolved in $2 \mathrm{~mL}$ of DMSO (dimethyl sulphoxide) and diluted with $200 \mathrm{~mL}$ of Tris buffer previously warmed at $37^{\circ} \mathrm{C}$. This solution was freshly prepared each day of the analysis and kept at $37{ }^{\circ} \mathrm{C}$ while in use.

Standard trypsin solution: $22 \mathrm{mg}$ of porcine pancreas trypsin was completely dissolved in $0.001 \mathrm{M} \mathrm{HCl}$ and made up to $1 \mathrm{~L}$ with $0.001 \mathrm{M} \mathrm{HCl}$. When subjected to the analytical procedure for the standard, $2 \mathrm{~mL}$ of this solution gave an absorbance value in the range of 0.410 \pm 10 after subtracting the reagent blank at $410 \mathrm{~nm}$.

\section{Analytical procedure}

Inhibitor extraction: The prepared flour samples were sieved through a $100 \mu \mathrm{m}$ mesh sieve and from each sample exactly $1 \mathrm{~g}$ was measured into separate plastic bottles of the same size (small). $25 \mathrm{~mL}$ of $0.0045 \mathrm{M} \mathrm{NaOH}$ was added and the bottles were kept in a shaker for $1 \mathrm{~h}$ at room temperature. The $\mathrm{pH}$ of the slurry was maintained between $9.4-9.6$ by the addition of $1 \mathrm{M} \mathrm{HCl}$.
Heat treatment and dilution: Extracted suspensions of each sample were divided into two equal portions and one portion from each sample was heated at $100{ }^{\circ} \mathrm{C}$ for 5 mins. Heated extracts were diluted 20 times while the extracts that were not heated were diluted 40 times with distilled water so that one (1) $\mathrm{mL}$ of suspension will produce trypsin inhibition of $40-60 \%$.

Determination of TIA: From each extracted suspension (heated and unheated) 18 test tubes were prepared in triplicate according to the compositions shown in Table 1. All the prepared test tubes were kept in a shaking water bath at $37^{\circ} \mathrm{C}$ for $10 \mathrm{~min}$ and $5 \mathrm{~mL}$ of BAPNA solution at $37^{\circ} \mathrm{C}$ was added into each tube at 30 s time intervals. The contents of the tubes were mixed using the Vortex mixture for $10 \mathrm{~s}$ after each addition. The tubes in the shaking water bath were incubated at $37{ }^{\circ} \mathrm{C}$ for $10 \mathrm{~min}$. $1 \mathrm{~mL}$ of $30 \%$ acetic acid solution was added to each tube to stop the reaction within $30 \mathrm{~s}$ time intervals. $2.0 \mathrm{~mL}$ of trypsin solution was added into each blank tube and filtered through Whatman no. 3 filter papers $(9 \mathrm{~cm})$. The absorbance due to release of $p$ - nitroaniline of each tube was recorded at $410 \mathrm{~nm}$.

\section{Calculation of results}

TIA $=$ mg of pure trypsin inhibited $/ g$ of sample

$$
\mathrm{TIA}=\frac{2.632 \times \mathrm{D} \times \mathrm{A}_{1}}{\mathrm{~S}}
$$

Where, $\mathrm{D}=$ Dilution factor

$\mathrm{A}_{1} \quad=$ Change of absorbance due to inhibition

$\mathrm{S}=$ Sample weight

$2.632=$ Constant figure based on the weight of pure trypsin inhibited per $\mathrm{mL}$

$A_{1}=$ Change in absorbance due to trypsin inhibition per $1 \mathrm{~mL}$ of diluted heated or unheated sample

$A_{1}=\left(A_{S t d}-A_{S t d B}\right)-\left(A_{S}-A_{B}\right)$

$\%$ Inhibition in each sample $=100 \mathrm{~A}_{1} /\left(\mathrm{A}_{\mathrm{Std}}-\mathrm{A}_{\mathrm{StdB}}\right)$

Table 1: Reagent composition in extracted suspensions

\begin{tabular}{lcccccc}
\hline & \multicolumn{2}{c}{ Standard } & \multicolumn{2}{c}{ Un - Heated sample } & \multicolumn{2}{c}{ Heated sample } \\
& $\begin{array}{c}\text { Blank } \\
\text { (Std B) }\end{array}$ & $\begin{array}{c}\text { Standard } \\
(\mathrm{Std})\end{array}$ & $\begin{array}{c}\text { Blank } \\
(\mathrm{UHB})\end{array}$ & $\begin{array}{c}\text { Sample } \\
(\mathrm{UHS})\end{array}$ & $\begin{array}{c}\text { Blank } \\
(\text { HB) }\end{array}$ & $\begin{array}{c}\text { Sample } \\
(\mathrm{HS})\end{array}$ \\
\hline Distilled water $(\mathrm{mL})$ & 2.0 & 2.0 & 1.0 & 1.0 & 1.0 & 1.0 \\
Trypsin solution $(\mathrm{mL})$ & - & 2.0 & - & 2.0 & - & 2.0 \\
$\begin{array}{l}\text { Diluted inhibitor suspension }(\mathrm{mL}) \\
\text { * }\end{array}$ & - & - & 1.0 & 1.0 & 1.0 & 1.0 \\
$\begin{array}{l}\text { Trypsin solution after reaction } \\
\text { inactivation }(\mathrm{mL})\end{array}$ & 2.0 & - & 2.0 & - & 2.0 & - \\
\hline
\end{tabular}




\section{Statistical analysis}

Triplicated results for various locations and mean values obtained for different cultivars were analysed using one way ANOVA by Tukey's HSD test $(p<0.05)$ using statistical software MINITAB version 14 for windows.

\section{RESULTS AND DISCUSSION}

\section{Flour extractability and chemical composition}

The results indicate that the extractability of flour from fresh roots lies in the range of $14.9 \pm 0.5$ to $35.5 \% \pm 1.1$. Flour extractability from each cultivar was significantly different at $\mathrm{p}>0.05$ level (Table 2). The moisture contents are in the range of $65.0 \pm 3.4$ to $74.6 \% \pm 1.9$ and usually the moisture level in sweet potato is around $75 \%$. The amount of dry matter and moisture content depends on the genotype, water balance at harvest, certain physiological factors and the conditions and time of storage. The soil moisture levels during the growing season can significantly affect the dry matter and moisture levels in sweet potato roots. The dry matter content of the samples ranging from 17.9 to $49.3 \%$ has been reported by Purcell et al. (1972).

Constantin et al. (1974) reported that when the available soil moisture levels were above $25 \%$, it caused the reduction in dry matter content thus increasing the moisture level in roots. Although the storage of roots can reduce the dry matter content due to respiration and carbohydrate conversion, it was found that the ratio between dry matter and moisture remained nearly constant during storage (Anderson, 1956).

The protein level in the cultivars studied were significantly different at $\mathrm{p}>0.05 \%$ level and lies in the range of $1.2 \pm 0.1$ to $3.3 \% \pm 0.1$. The highest amount of protein was observed in CARI 273 and the lowest was in Wariyapola red (Table 2). Literature reveals that protein levels in sweet potato roots range from 1.73 to $10.0 \%$ on dry basis (Purcell et al., 1984; Bradbury et al., 1985). Woolfe in 1992 found that the protein in sweet potato roots contained an appreciable level of the amino acid lysine, which is deficient in rice. It was found that the heat processing reduces the amino acid content in sweet potato roots (Walter \& Purcell, 1986). Purcell et al. (1972) investigated the amount of essential amino acid levels in the roots of sweet potato and all were above the FAO reference level. Thus the protein available in sweet potato is of high quality and efforts should be made to maximize the production and wider consumption of this crop by the people.

\section{Analysis of TIA in heated and unheated samples}

There was a wide variation in TIA of different sweet potato cultivars (Table 3 ). The range of TIA in unheated root flour samples was $1.9 \pm 0.01$ to $15.4 \pm 0.4$ and in heated sample the value lies between $0.156 \pm 0.01$ and $13.0 \pm 0.01$ range. The results clearly show a significant reduction of TIA in heated samples compared to the unheated samples. Bradbury et al. (1985) reported a larger range of variation in TIA of roots among 30 Papua New Guinean cultivars.

Qualitative and quantitative differences of trypsin inhibitor proteins in sweet potato may be responsible for the wide variation in the TIA among different cultivars. Seven different trypsin inhibitor bands have been identified by Dickey \& Collins (1984) through electrophoresis of roots of four cultivars of sweet potatoes. It is also known that the genotype and the environmental factors collectively affect the TIA of the roots of sweet potato (Bradbury et al., 1985; Ravindran et al., 1995).

The roots of sweet potato contain much higher levels of TIA than the other parts such as vines and leaves of the crop. There was a wide variation in TIA levels among the different genotypes of sweet potato roots. A 167 fold range of TIA in 30 cultivars has been reported by Bradbury et al. in 1985. Sporamin, which is the main storage protein in sweet potato is also found to be the

Table 2: Moisture, protein content and flour extractability of sweet potato cultivars

\begin{tabular}{llll}
\hline Cultivar & Moisture content (\%) & Crude protein* db (\%) & Flour extractability \\
\hline Wariyapola red (SWP1) & $70.1 \pm 1.7^{\mathrm{b}}$ & $1.2 \pm 0.1^{\mathrm{e}}$ & $14.9 \pm 0.5^{\mathrm{e}}$ \\
Wariyapola white (SWP3) & $65.8 \pm 2.5^{\mathrm{c}}$ & $3.0 \pm 0.1^{\mathrm{b}}$ & $35.5 \pm 1.1^{\mathrm{a}}$ \\
Pallepola (SWP4) & $74.6 \pm 1.9^{\mathrm{a}}$ & $2.3 \pm 0.1^{\mathrm{c}}$ & $28.5 \pm 0.5^{\mathrm{c}}$ \\
Malaysian (SWP5) & $71.0 \pm 0.5^{\mathrm{b}}$ & $1.7 \pm 0.2^{\mathrm{d}}$ & $25.8 \pm 0.4^{\mathrm{d}}$ \\
CARI 273 (SWP7) & $65.0 \pm 3.4^{\mathrm{c}}$ & $3.3 \pm 0.1^{\mathrm{a}}$ & $30.6 \pm 0.5^{\mathrm{b}}$ \\
\hline
\end{tabular}

Note: Data represent the mean of three replicates. Values followed by the different superscript in each column are significantly different at $\mathrm{p}>0.05, *(\mathrm{~N} \times 6.25)$ 
most prominent trypsin inhibitor in this crop. Heat treatment at elevated temperatures reduced the inhibition efficiency and the concentration of sporamin B with trypsin inhibitor activity, despite the fact that sporamin B shows high heat stability (Lin, 1993). It was also reported that heat treatment of sweet potato root extracts exceeding $90{ }^{\circ} \mathrm{C}$ may induce denaturing of sporamin $\mathrm{B}$ rapidly. The study also revealed that longer treatment time at $100{ }^{\circ} \mathrm{C}$ led to a rapid reduction in the TI activity.

Table 3: Trypsin inhibitory activity of heated and unheated samples (mg trypsin inhibited /g sample)

\begin{tabular}{lll}
\hline Sample & Per/g sample (db) & Per/g protein $(\mathrm{db})$ \\
\hline Wariyapola red (H) & $0.156 \pm 0.01^{j}$ & $12.09 \pm 0.1^{j}$ \\
Wariyapola white (H) & $3.03 \pm 0.03^{f}$ & $94.2 \pm 0.6^{g}$ \\
Pallepola (H) & $13.0 \pm 0.01^{b}$ & $525.2 \pm 0.6^{b}$ \\
Malaysian (H) & $1.56 \pm 0.01^{i}$ & $87.5 \pm 0.5^{h}$ \\
CARI 273 (H) & $2.87 \pm 0.01^{g}$ & $79.5 \pm 0.1^{i}$ \\
Wariyapola red (UH) & $1.9 \pm 0.01^{h}$ & $153.5 \pm 0.3^{f}$ \\
Wariyapola white (UH) & $6.2 \pm 0.02^{d}$ & $192.2 \pm 0.1^{e}$ \\
Pallepola (UH) & $15.4 \pm 0.4^{a}$ & $628.2 \pm 0.1^{a}$ \\
Malaysian (UH) & $3.8 \pm 0.1^{e}$ & $215.9 \pm 0.3^{c}$ \\
CARI 273 (UH) & $7.0 \pm 0.1^{c}$ & $194.7 \pm 0.2^{d}$ \\
\hline
\end{tabular}

H: Heated, UH: Unheated. Data represent the mean of three replicates. Values followed by the different superscript in each column are significantly different $(\mathrm{p}>0.05)$.

The lowest TIA level was observed in Wariyapola red and the highest level was in Pallepola cultivar (Table 3). Results showing lower TIA sometimes may be due to the presence of relatively larger levels of noninhibitory proteins, which can react with added trypsin thus reducing the chances of reacting BAPNA with pure trypsin added. The extraneous proteins present in the crude sample extracts may also have a non-specific effect by interacting with the resulting $p$ - nitrophenol due to the reaction of BAPNA with trypsin. Such adsorptions with insoluble proteins may probably give low values for TIA, which may be high otherwise. Even though the presence of bound or inactive forms of trypsin inhibitors may cause doubtful situations, under the method employed, TIA is given by all the inhibitors that are able to interact with added trypsin under the given conditions. In more alkaline conditions it is found to have high values for TIA due to the presence of fat or phospholipids acting as trypsin inhibitors. Due to this reason the maintenance of $\mathrm{pH}$ at $9.4-9.6$ during the extraction is very important.

The results also revealed that heating the samples at $100{ }^{\circ} \mathrm{C}$ for 5 minutes has reduced the TIA at $\mathrm{p}>0.05 \%$ level of significance and considerable levels of TIA remained in heated samples. There are reports of insoluble forms of trypsin inhibitors in heated soy flour extracts active in this assay method (Kakade et al., 1974) and the inactive forms of TI can be activated at $\mathrm{pH}$ between 7 - 9 (Ramsey $\&$ Willard, 1975). Also the masked forms of TI can be activated by treatment with acids (Smith et al., 1980).

Lin (1989) reported that heating at $100{ }^{\circ} \mathrm{C}$ for 15 minutes completely inactivate the original TIA in sweet potato root flour samples. Inactivation of TI by heat treatment may improve the protein quality and thereby increase the nutritive quality of the food stuff. Wariyapola white, Malaysian and CARI 273 cultivars contained fairly low levels of TI in unheated form and it is even low in heated samples. High level of TIA in Pallepola cultivar may be due to a different type of TI and / or due to variations in environmental factors (Ravindran et al., 1995).

The TIA level per gram of protein was significantly higher in heated samples of Pallepola cultivar and very low in Malaysian cultivar. Literature reveals that about $80 \%$ of the storage protein in the root comes from the trypsin inhibitors. The amount of TIA $\mathrm{mg} / \mathrm{g}$ protein is quite high in sweet potato roots compared to high protein foods such as soya bean $(69-105 \mathrm{mg} / \mathrm{g})$. Many attempts have been made by researchers to develop sweet potato varieties with high protein content and / or low trypsin inhibitor activity (Toyama et al., 2006). Although the consumption of sweet potato roots after boiling in water, coconut milk and spices for a few minutes may reduce the TIA to a greater extent, the existing quality of protein might be questionable. Thus it is necessary to screen the cultivars with high protein content and low TIA, and also to identify successful processing methods to reduce the TIA levels in order to effectively improve the utilization of sweet potato roots as a nutritive starchy food. For a more conclusive study it is necessary to analyse the TIA levels in sweet potato roots boiled and cooked with various other food ingredients, the way people consume it in Sri Lanka. This will give a more clear idea about the activity of trypsin inhibitors in this food commodity.

\section{CONCLUSION}

The results of this study indicated that heat processing of sweet potato roots reduced the TIA to a significant level. TIA level in Wariyapola red cultivar was considerably low compared with other cultivars studied and the highest level was reported in Pallepola cultivar. Wariyapola white, Malaysian and CARI 273 cultivars contained moderate levels, both when heated and unheated. The TIA level per gram of protein was comparatively low in Wariyapola red, 
Wariyapola white, Malaysian and CARI 273 cultivars and the former was found to be the lowest. When considering the amount of dry matter, protein content and the level of TIA per gram of available protein, CARI 273 can be considered as the most significant cultivar on the basis of nutritive quality. It is necessary to study the TIA levels where various culinary methods are used by the people of this country for a more conclusive study.

\section{Acknowledgement}

The authors thank the Horticultural Crop Research Institute, Gannoruwa, Sri Lanka for the support extended and the University of Sri Jayewardenepura for providing financial assistance.

\section{REFERENCES}

1. Alves R.M., Grossmann M.V., Ferrero C., Zaritzky N.E., Martino M.N. \& Sierakoski M.R. (2002). Chemical and functional characterization of products obtained from yam tubers. Starch/Stärke 54: 476 - 481.

2. Anderson W.S. (1956). Some effect of curing and storage on the weight and carotene content of certain sweet potato varieties. Proceedings of the American Society of Horticultural Science 71: 412 - 417.

3. Association of Official Analytical Chemistry (AOAC) (1980). Official Methods of Analysis, volume 1. Association of Official Analytical Chemistry, Gaithersburg, USA.

4. Bouwkamp J.C., Tsou S.C.S. \& Lin S.S.M (1985). Genotype and environmental effects on the relationship between protein concentration and trypsin inhibitor levels in sweet potato. Hortscience 20: $886-889$.

5. Bradbury J.H., Hammer B., Nguyen T., Anders M. \& Millar J.S. (1985). Protein quantity and quality and trypsin inhibitor content of sweet potato cultivars from the Highlands of Papua New Guinea. Journal of Agricultural and Food Chemistry 33:281 - 285.

DOI: http://dx.doi.org/10.1021/jf00062a032

6. Cai D.G., Tim T., Tian Y.Y., Lange T., Yeh K.W. \& Jung C. (2003). Sporamin - mediated resistance to beet cyst nematodes (Heterodera schachtii Schm.) dependant on trypsin inhibitory activity in sugar beet (Beta vulgaris L.) hairy roots. Plant Molecular Biology. 51: 839 - 849 .

DOI: http://dx.doi.org/10.1023/A:1023089017906

7. Constantin R.J., Hernandez T.P. \& Jones L.G. (1974). Effects of irrigation and nitrogen fertilization on quality of sweet potatoes. Journal of the American Society of Horticultural Science 99: 308 - 310.

8. Deptartment of Census and Statistics Sri Lanka (DCS) (1999). Food Balance Sheets. Agriculture and Environment Statistics Division, Department of Census and Statistics, Colombo.

9. De Silva K.P.U. \& Jayawardene S.D.C. (1989). Indigenous and recent advances in sweet potato production, processing and marketing in Sri Lanka.
Research Information Ltd., Herefordshire, UK.

10. Dickey L.F. \& Collins W.W. (1984). Cultivar differences in trypsin inhibitors of sweet potato roots. Journal of the American Society of Horticultural Science 109: 750 - 754.

11. Jiao J.A., Yee B.C., Kobrehel K. \& Buchanan B.B. (1992). Effect of thioredoxin - linked reduction on the activity and stability of the Kunitz and Bowman - Birk soybean trypsin inhibitor proteins. Journal of Agricultural and Food Chemistry 40: 2333 - 2336.

DOI: http://dx.doi.org/10.1021/jf00024a002

12. Kakade M.L., Rackis J.J., Mcghee J.E. \& Puski G. (1974). Determination of trypsin inhibitor activity of soy products: a collaborative analysis of an improved procedure. Cereal Chemistry 51: $376-382$.

13. Kobrehel K., Wong J.H., Balogh A., Kiss F., Yee B.C. \& Buchanan B.B. (1992). Specific reduction of wheat storage proteins by thioredoxin h. Plant Physiology 99: 919 - 924. DOI: http://dx.doi.org/10.1104/pp.99.3.919

14. Liener I.H \& Kakade M.L. (1969). Protease inhibitors. Toxic Constituents of Plant Foodstuffs (ed. I.E. Liener), pp. 8-68. Academic Press. New York and London.

15. Lin Y.H. (1989). Relationship between trypsin - inhibitor activity and water - soluble protein and cumulative rainfall in sweet potato. Journal of the American Society of Horticultural Science 114: 814 - 818.

16. Lin Y.H. (1993). Trypsin inhibitors of sweet potato: review and prospect. Recent Advances in Botany, Monograph Series 13 (eds. Y.I. Hsing \& C.H Chou), pp. 179 - 185. Academia Sinica, Taipei.

17. Matsuoka K., Matsumoto S., Hattori T., Machida Y., Nakamura K. \& Maeshima M. (1990). Vacuolar targeting and post translational processing of the precursor to the sweet potato tuberous root storage protein in heterologous plant cells. The Journal of Biological Chemistry 265: 19750 $-19957$.

18. Onwueme I.C. (1978). Sweet potato. The Tropical Tuber Crops Yams, Cassava, Sweet Potato, Cocoyams, pp. 167 - 175. John Wiley and Sons, Chichester, UK.

19. Purcell A.E., Walter W.M. \& Wilson L.G. (1984). Sweet potatoes. Quality and Preservation of Vegetables (ed. N.A. Michael), pp 285 - 304. CRC Press, New York, USA.

20. Purcell A.E., Swaisgood H.E. \& Pope D.T. (1972). Protein and amino acid content of sweet potato cultivars. Journal of the American Society of Horticultural Science 97: 30 - 33.

21. Ramsey H.A. \& Willard T.R. (1975). Soy protein for milk replacers. Journal of Dairy Science 58: 436 - 441.

22. Ravindran V., Ravindran G., Sivakanesan R. \& Rajaguru S.B. (1995). Biochemical and nutritional assessment of tubers from 16 cultivars of sweet potato (Ipomea batatas L). Journal of Agricultural and Food Chemistry 43: 2646 -2651 .

DOI: http://dx.doi.org/10.1021/jf00058a017

23. Ryan C.A. (1989). Protease inhibitor gene families: strategies for transformation to improve plant defenses against herbivores. Bioassays 10: 20 - 24.

DOI: http://dx.doi.org/10.1002/bies.950100106

24. Smith C., Van Megan W., Twaalfhoven L. \& Hitchcock C. (1980). The determination of trypsin inhibitor levels in food 
- stuffs. Journal of the Science of Food and Agriculture. 31: $341-350$.

DOI: http://dx.doi.org/10.1002/jsfa.2740310403

25. Sohonnie K. \& Bhandarker A.P. (1954). Trypsin inhibitors in Indian foodstuff: I. Inhibitors in vegetables. Journal of Scientific and Industrial Research 13B: 500 - 503.

26. Sugiura M., Ogiso T., Takeuti K., Tamura S. \& Ito A. (1973). Studies on trypsin inhibitors in sweet potato. I. purification and some properties. Biochemica et Biophysica Acta 328: $407-417$.

27. Toyama J., Yoshimoto M. \& Yamakawa O. (2006). Selection of sweet potato lines with high protein content and/or low trypsin inhibitor activity. Breeding Science 56: $17-23$. DOI: http://dx.doi.org/10.1270/jsbbs.56.17

28. Walter W.M. \& Purcell A.E. (1986). Protein of sweet potato.
ACS Symposium Series 312: 234 - 248.

29. Woolfe J.A. (1992). Sweet Potato: An Untapped Food Resource, pp 409 - 472. Cambridge University Press, Cambridge, UK.

30. Yan - Li S., Jun - Mao S. \& Qing - Peng L. (2009). Purification and trypsin inhibitor activity of sporamin B from sweet potato (Ipomea batatas Lam. 55-2). Agricultural Sciences in China 8(7): 808 - 820.

31. Zhang D., Collins W.W. \& Andrade M. (1998). Genotype and fertilization effects on trypsin inhibitor activity in sweet potato. HortScience 33: 225 - 228.

32. Zhang Z., Wheatley C.C. \& Corke H. (2002). Biochemical changes during storage of sweet potato roots differing in dry matter content. Postharvest Biology and Technology 24: $317-325$. 